IRSH 60 (2015), Special Issue, pp. 227-25 I doi:I0.1017/So0208590 I 5000474 (C) 2015 Internationaal Instituut voor Sociale Geschiedenis

\title{
Dissimilarity Breeds Contempt: Ethnic Paternalism, Foreigners, and the State in Pas-de-Calais Coalmining, France, 1920s*
}

\author{
Philip H. Slab Y \\ Department of History, Guilford College \\ Archdale Hall 20I, Greensboro, NC 274IO, USA
}

E-mail: pslaby@guilford.edu

\begin{abstract}
Recently, historians have begun to illuminate further the role that ethnicity played in integrating immigrants into mining societies. Ethnicity, they show, shaped foreign-native relations in complex ways. Migrant culture and local norms both affected the assimilation process. This essay, focusing on France's premiere coalfield of Pas-de-Calais during the i 920s, a period of mass influx of Polish laborers, explores employers' often underappreciated influence over inter-ethnic relations, and it reveals the far-reaching effects of managerial policies. Management's ethnic paternalism influenced, though often unintentionally, relations between Poles and French miners and officials. Employer strategies to manage Poles led natives to see themselves as distinct from and even superior to immigrants. Beyond the workplace, employers used ethnic notions to attract and control Poles, yet in doing so they highlighted the dissimilarities between Poles and Frenchmen. Ultimately, coal companies reinforced foreigners' isolation from local society and roused the suspicions of officials, who strictly policed the Polish community.
\end{abstract}

The decade after World War I was one of uncertainty for coal companies, for miners, and for government officials in the French department of Pas-de-Calais, the site of France's most important coalfield. Heavy fighting and a destructive German invasion had devastated the region's mines, infrastructure, and communities. For much of the I920s, mining firms faced unsettling prospects: could they re-establish and expand production in a postwar economy hobbled by labor shortages? Pas-de-Calais miners also

\footnotetext{
* I would like to thank Ad Knotter, David Mayer, and the participants of the workshop "Migration and Ethnicity in Coalfield History" held at the Netherlands Institute for Advanced Study in November 20I4 for their comments and input on this essay.
} 
grappled with thorny questions: could they or would they return to the jobs and communities many had fled during the war? And if so, what economic and social future awaited them? Further specific concerns weighed on local government officials: how could they restore and ensure political stability and national security in a border region once victim to foreign occupation?

For the coal industry, a solution to labor scarcity and a means to revival appeared in the arrival of tens of thousands of workers from eastern Europe, especially Poland. This immigration, however, raised new questions of how to attract, train, retain, and manage foreigners. Firms developed policies to address these issues, strategies that created a large Polish workforce in the mines and that contributed to a vibrant Polish community in the coalfields. By doing so, however, management amplified the postwar anxieties of French miners and authorities in Pas-de-Calais.

The challenges that coal companies, mining communities, and officials faced in the postwar Pas-de-Calais were not wholly unique. Indeed, mines worldwide and across time have relied upon workers migrating from within and without national borders to staff their facilities. They have thus helped to create in mining regions a host of multi-ethnic workforces and societies. Various forces shaped the acceptance of newcomers in mines, in coalfield communities, and in nations. In the past decade, scholars have increasingly illuminated the powerful influence that ethnicity and local, regional, and national identities exerted over the occupational and social position of migrant miners. They show that ethnic and other identities, varying by place and evolving over time, have shaped the attitudes and actions of foreigners and natives alike. Coalfield historians have particularly highlighted how the views and values of indigenous miners affected immigrant-native interaction in the workplace and beyond. Further, recent scholarship has suggested that native ethnic identities also influenced the valuations and actions of state authorities and of coal company leaders as they policed and managed immigrants. ${ }^{\mathrm{I}}$

This essay builds on recent scholarly insights to examine the complex ways in which ethnicity and local, regional, religious, and national identities shaped the treatment that Poles received from the Pas-de-Calais miners who toiled with them, the local officials who governed and policed them, and the executives and managers who supervised them. It focuses on the decade after World War I, a period significant for various reasons. First, in these years, the number of Poles in the Pas-de-Calais coal basin and mines rapidly grew and then stabilized. Second, the period held managerial significance as one in which firms devised and then institutionalized policies

I. For a view of how these concerns, among other questions, have shaped scholarship, see Stefan Berger, Andy Croll, and Norman LaPorte (eds), Towards a Comparative History of Coalfield Societies (Burlington, VT, 2005). 


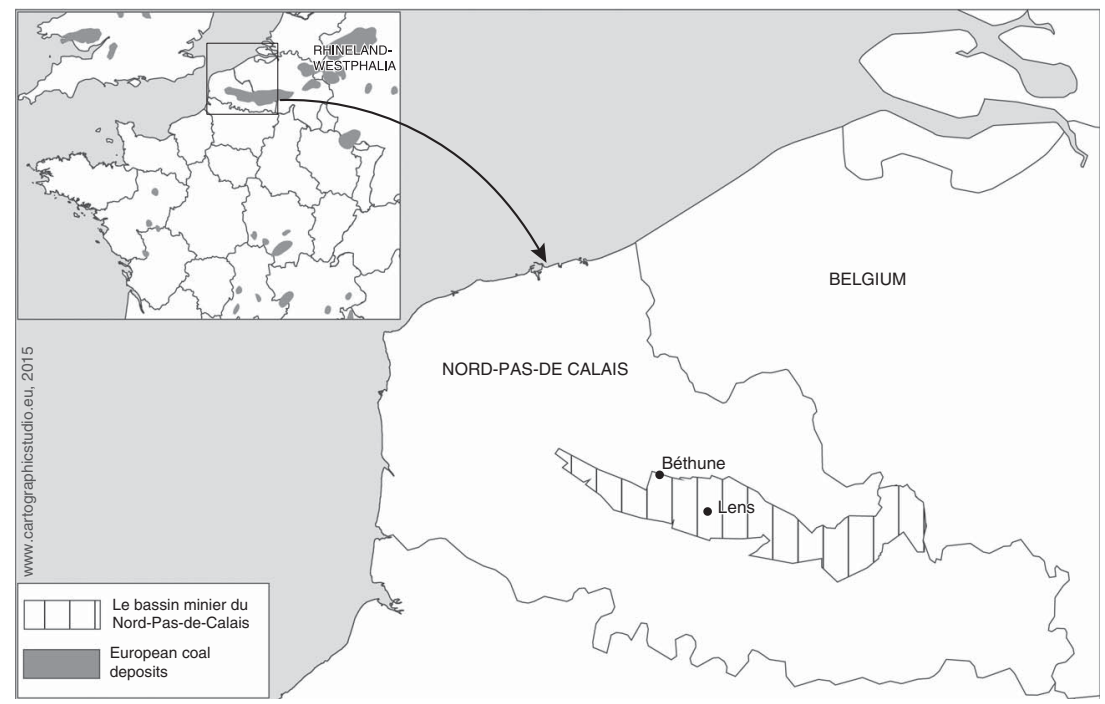

Figure I. The department of the Pas-de-Calais occupies the western portion of the Nord-Pasde-Calais region figured here. The Pas-de-Calais coalfields comprise the western half of the Nord-Pas-de-Calais coal basin.

toward Polish personnel. Third, it was a decade in which Pas-de-Calais natives completed, as best they could, the transition from war, destruction, and dislocation to a new postwar situation. Yet it remained a period in which native attitudes remained clouded by the experience of war and the burdens of rebuilding. Lastly, the I920s proved a formative period for Polish-French relations in Pas-de-Calais. Indeed, the occupational and social position that Poles came to inhabit and the patterns of interaction between the immigrants and local French employers, miners, and officials that developed in that time largely characterized those of the larger interwar period.

This essay seeks to deepen scholarly understanding of the power of ethnicity and identity to shape immigrant integration into mining societies, by exploring the often underappreciated influence of coal companies and their policies over inter-ethnic relations. It reveals the far-reaching effects that managerial policies carried for French-Polish interaction and the complex influences that ethnic and national identities exerted over group perceptions. Managerial policies inside and outside the mines greatly influenced, though often unintentionally, relations between immigrants and coalfield natives and local French officials. In the workplace, employer strategies to assign, to train, and to manage Polish workers led French miners to see themselves as distinct from and even superior to immigrants, a view that impeded workplace ties between natives and newcomers. 
Beyond the workplace, ethnic notions helped guide employer efforts to attract, to maintain, and to control Poles, as firms revamped company housing and paternalist support for religious and voluntary associations to accommodate and benefit from the immigrants' particular cultural preferences. Such ethnic paternalism highlighted the ethnic and national dissimilarities between Poles and Frenchmen in the coalfields. Ultimately, it reinforced the foreigners' isolation from local working-class society and its institutions. Company ethnic paternalism also influenced the relationship between immigrant Poles and the French state. By creating Polish neighborhoods, by fostering Polish clubs and associations, by supporting Polish clergy and religious institutions, and by taking a cooperative position toward representatives of the Polish state in the region, coal companies fostered an immigrant community that aroused the suspicions of local state officials. And from suspicion discrimination grew, as local officials, keen to protect the security and power of the French republic, strictly policed and harshly punished members of the Polish community.

\section{LABOR SCARCITY AND THE CHALLENGES}

\section{AND OPPORTUNITIES OF POLISH IMMIGRATION}

After World War I, the Pas-de-Calais mines faced a dearth of workers that threatened the coal industry's postwar recovery and future productivity. Before I9I4, executives managed their operations confidently, relying on abundant and stable local labor. The war swept away such certainties. German occupation and heavy fighting transformed the coalfields into a battle zone. Materially, the war devastated the region's mines, cities, and infrastructure, and reconstruction demanded a great mass of workers. At the same time, the war restricted labor supply. Military service cost the mines thousands of workers, as an estimated 22 per cent of all Pas-de-Calais miners mobilized never returned from the war. ${ }^{2}$ Population displacement wrested away still more workers. Thousands fled the German invasion and combat in the region; migrating elsewhere in France, many never came back. Civilian flight also sapped labor supply by arresting apprenticeships. Indeed, during four years of war, no young apprentices trained as miners in Pas-de-Calais. $^{3}$

2. Paul Georges, "Rapport de M. L'Ingénieur en Chef des Mines sur la Situation de l'Industrie minérale dans l'Arrondissement minéralogique d'Arras pendant l'Année 1922", in Département du Pas-de-Calais Conseil Général, deuxième session de 1923, Troisième Partie Rapports des Chefs de Service et Renseignements divers (Arras, I923), pp. 3 I I-349, 320-32 I; "La main-d'œuvre dans les Mines du Pas-de-Calais, I", Nord Industriel, (1923), p. I460. Unless indicated otherwise, articles from the Nord Industriel - a fortnightly journal about and for the north's industries - did not specify any author.

3. Georges, "Rapport de M. L’Ingénieur en Chef des Mines [...] I922", pp. 318 and 320. 
Beyond demographic change, shifting postwar social and cultural attitudes among Pas-de-Calais workers contributed to postwar labor shortages. Indeed, wartime upheavals aroused new ambitions among coal basin natives. In fact, immediately after the armistice, industry observers reported significant transformations in the "aspirations of workers". ${ }^{4}$ One mining engineer noted that after the war miners wished "to live in a more bourgeois manner". This shift in the outlook of miners was reflected in their evaluations of work. Miners no longer venerated physical brawn and adeptness. On the contrary, the greater "intelligence" a position demanded, the more they valued it. They increasingly esteemed office personnel as "intellectual workers", and they admired tradesmen such as pipe fitters, electricians, and machinists. ${ }^{5}$ Miners aspiring to less taxing and more lucrative positions indeed found jobs both inside and outside the postwar coal industry. Rebuilding and modernizing the mines produced much service and maintenance work. ${ }^{6}$ Such attractive positions remained plentiful for much of the I920s, providing miners with alternatives to toiling underground. ${ }^{7}$ Other Pas-de-Calais workers avoided mining altogether. Instead, they found positions restoring war-damaged buildings and infrastructure, jobs employing thousands in Pas-de-Calais until the mid-r $920{ }^{8}{ }^{8}$

4. "La Raréfaction de la Main-d'œuvre et les Méthodes d’Exploitations des Mines: Développement probable des Machinisme dans les Mines, I", Nord Industriel, (I92 I), p. 329.

5. See the following contemporary analysis: John Condeveaux, Le Mineur du Nord et du Pas-deCalais: sa Psychologie, ses Rapports avec le Patronat (Lille, I928), pp. I4-16.

6. "La Raréfaction de la Main-d'œuvre [...], I", p. 329.

7. Georges, "Rapport de M. L’Ingénieur en Chef des Mines [...] I 922 ”, p. 3 I 8; idem, "Rapport de M. L'Ingénieur en Chef des Mines sur la Situation de l'Industrie minérale dans l'Arrondissement minéralogique d'Arras pendant l'Année 1925", in Département du Pas-de-Calais Conseil Général, Troisième Partie Rapports des Chefs de Service et Renseignements divers (Arras, 1926), pp. 97-I I I, I04. 8. Archives départementales of Pas-de-Calais, Dainville [hereafter, ADPdC], Series IZ Subprefecture IZ209, 25 March 1924, Prefecture du Pas-de-Calais to Ministère du Travail, 25 March 1924. The archival sources for this essay are drawn from two institutions. First, the departmental archives of the Pas-de-Calais in Dainville provide official information, observations, and opinions regarding immigrants in the Pas-de-Calais coalfields. In particular, the analysis employs documents held in the $\mathrm{M}$ series devoted to general prefectoral administration in the department. Important here are files $\mathrm{M}_{3229}$ Groupements de main-d'ceuvre étrangère dans le Pas-de-Calais, I925, $\mathrm{M}_{323} \mathrm{I}$ Rapports général sur Immigrés polonais, and M68 57 Immigrants polonais: renseignements généraux. It also uses documents in the IZ series comprised of documents from the subprefecture of Béthune. Important here are files IZ209 Étrangers: Divers, 1919-1925, IZ277 Syndicat des mineurs, 1924I926, and IZ5OI Polonais, I924-1935. The second archival institution central to this essay is the Archives Nationales du Monde du Travail [hereafter, ANMT] in Roubaix. These archives permit an appreciation of the place of immigrant labor in the coal industry. This study makes particular use of the papers and publications of the coalmine employer association held in the $40 \mathrm{AS}$ series Comité Central des Houillères de France [hereafter, CCHF], especially files $40 \mathrm{AS}_{\mathrm{I}}$ and $40 \mathrm{AS} 7$. It also uses the papers of the individual coal companies held in the series 1994 Houillères $d u$ Bassin $d u$ Nord et $d u$ Pas-de-Calais. The essay draws on the files in 1994 050 Houillères $d u$ Bassin $d u$ Nord et $d u$ Pas-deCalais, Compagnie des Mines de Bruay, and most extensively on the documents in 1994048 Houillères du Bassin du Nord et du Pas-de-Calais, Mines de Marles. 
Indeed, reflecting displeasure with mining, turnover among French workers remained high in the mines. ${ }^{9}$

Facing a limited and unreliable pool of native labor, firms turned to immigrants to fill gaps in the workforce. And it was workers from Poland which the Pas-de-Calais mines were most successful in contracting. By hiring tens of thousands of them, they overcame postwar personnel shortages. The arrival of immigrants was massive, sudden, and altered the composition of the mining labor force. Before the war, foreign manpower played no significant role in Pas-de-Calais mines. Beginning in I9I9, the arrival of Poles and other immigrants dramatically increased the foreign presence. By 1922, the number of immigrant workers topped 21,500, or 26 per cent of the entire mining staff. ${ }^{10}$ By 1924, some 50,000 foreigners comprised more than 40 per cent of the labor force. ${ }^{I I}$ Though immigrant recruitment ebbed and flowed from 1925 to I93 I, foreign manpower remained significant. In fact, in this period French workers seldom formed more than 60 per cent of the Pas-de-Calais mining workforce. ${ }^{\mathrm{I2}}$

Surging immigration also altered the traditional demographic and ethnic composition of Pas-de-Calais. Before the war, non-French residents of Pas-de-Calais, most of them from nearby Belgium, represented approximately 3 per cent of the department's inhabitants. By 1926, however, the number of non-native residents had grown sharply to over i 53,000 , or fully I 3 per cent of the Pas-de-Calais population. ${ }^{13}$ Polish immigration contributed mightily to this larger increase. From under 3,400 in I $92 \mathrm{I}$, the Polish population rose to 91,000 in 1926 , constituting 8 per cent of all Pas-de-Calais residents and the department's largest single immigrant group. ${ }^{\text {I4 }}$

For Pas-de-Calais coal firms seeking to make foreigners a productive component of their postwar workforce, attracting, incorporating, and maintaining immigrant staff presented a host of challenges. Enticing Poles to the mines was the first hurdle. Would-be Polish emigrants had options. They could choose to leave Poland for the mines or for other employers in France.

9. Pierre Galand, Les Mines du Nord et du Pas-de-Calais depuis la Guerre (Paris, 1936), p. 97. Io. Paul Georges, "Rapport de M. l'Ingénieur en chef des Mines sur la Situation de l'Industrie minérale dans l'Arrondissement minéralogique d'Arras pendant l'année 1923”, in Département du Pas-de-Calais Conseil Général deuxième Session ordinaire de 1924: Rapports des Chefs de service et Renseignements divers, troisième partie (Arras, I924), pp. I I3-I 36, I 28.

I I. Idem, "Rapport de M. l'Ingénieur en chef des Mines sur la Situation de l'Industrie minérale dans l'Arrondissement minéralogique d'Arras pendant l'année 1924", in Département du Pas-deCalais Conseil Général deuxième Session ordinaire de 1925: Rapports des Chefs de service et Renseignements divers, troisième partie (Arras, 1925), pp. I07-I 24, I I7-I I 8.

I 2. Galand, Les Mines $d u$ Nord, pp. 77 and I35.

I3. Michel Huber, La Population de la France pendant la Guerre (New Haven, CT, I93 I), p. 86I. I4. Georges Mauco, Les Étrangers en France: Étude géographique sur leur rôle dans l'activité économique (Paris, 1932), p. I66. 
They could select another country, or they could simply remain in Poland. Further, communication between immigrants and families and friends in Poland permitted emigrants to evaluate employment prospects abroad. Additionally, the Polish state influenced the flow of emigrants. If it discerned that certain foreign employers offered its citizens poor pay or treatment, it could forbid them to recruit in Poland. Thus, to attract Poles, the Pas-deCalais mines endeavored to ascertain the predilections of immigrant Poles and of their government. For instance, they noted that Polish workers welcomed, and that the Polish state approved of, opportunities to emigrate with their spouses and children. ${ }^{\text {IS }}$ They registered that immigrants much valued company housing, particularly single-family dwellings. ${ }^{16}$ Further, executives observed that Poles aspired to maintain ties with their native language, culture, and religion while abroad. ${ }^{17}$ Meeting such preferences would, they postulated, boost Polish labor recruitment.

Incorporating immigrants into the mines, ensuring their productivity as well as their continuance, created still other difficulties for managers. One of the issues was that many incoming Poles challenged job placements. While firms needed manpower underground above all, many immigrants pressed for jobs on the surface instead. ${ }^{18}$ Problems of productivity created still more complications. Newly contracted Poles often entered the mines without relevant skills. ${ }^{19}$ Even Poles with expertise - usually gained in German mines - initially extracted coal at rates below those of seasoned French workers. ${ }^{20}$ Additionally, a high turnover among non-native staff sapped production. Foreigners often abandoned their posts soon after their hiring. For instance, over one-third of the Poles entering French mines in I92 I abandoned the coal industry before the expiration of their one-year contracts. ${ }^{21}$ Mining executives, thus, regularly decried the impermanence of Poles, which left work teams shorthanded, disorganized, and unproductive. ${ }^{22}$

Though Polish workers created appreciable challenges for coal companies, they saw in the immigrants not only a source of much-needed labor but also opportunities to reshape the character of the workforce. Calculatingly,

I5. ANMT, I 994 050/0064, 8 January I92 I, CCHF circular 6i s.

16. ANMT, $40 \mathrm{AS} 7$, I 8 September 1920, Secretary of the CCHF, letter to mine directors.

17. André Pairault, L'Immigration organisée et l'Emploi de la Main-d'œuvre étrangère en France (Paris, I927), p. 257.

I8. ANMT, I994 048/003 I, Directions des Services techniques, Procès-Verbal de la Conférence 24 February 1921: Personnel du jour des sièges.

19. Auguste Pawlowski, "Un gros problème pour l'industrie du Nord: l'Assimilation des ouvriers étrangers”, Nord Industriel, (1925), p. 919.

20. “Aux mines d'Ostricourt”, Nord Industriel, (1924), p. I950.

21. ANMT, ${ }_{40} \mathrm{AS}$ I, CCHF Assemblée Générale I924, p. I 4. It is noteworthy that such figures on immigrant worker movement did not include the number of Poles who abandoned one mine for another.

22. Pairault, L'Immigration organisée, pp. I44-145. 
managers approved of the Poles' preference for family immigration and their tendency to have large families. Such traits appeared to be a means to stabilize the current labor force and to cultivate a future one. ${ }^{23}$ Additionally, the Poles' widespread devotion to Catholicism suggested that these immigrants shared management's preference for order, probity, and faith. ${ }^{24}$ The idea that the immigrants' cultural differences could be exploited for the mines' benefit tantalized the executives. If management could maintain the Poles' outlook and habits, it might isolate the immigrants from the trade unionism, political activism, secularism, and family planning that managers found troublesome among French miners. ${ }^{25}$

\section{MANAGING IMMIGRANTS AT THE COALFACE AND BEYOND}

To meet the challenges in recruiting, in job placement, in productivity, and in worker retention that immigrant labor posed, and to maximize the managerial advantages Polish miners presented, companies developed new supervisory policies in the workplace, a brand of ethnic paternalism outside it, and they took a cooperative stance toward Polish officials.

To address some of these difficulties, companies reshaped managerial strategies in the mines. First, firms developed placement procedures for immigrants to assure that they went to where they were most needed. The tactic was simple: companies such as the Mines de Marles deliberately withheld surface positions from non-natives. In fact, the company's general director ordered his engineers to "accord [Poles] no employment [on the surface] and to dismiss them if they refused to go down into [the pits]". ${ }^{26}$ Such policies at the Mines de Marles and across the coal basin overwhelmingly concentrated immigrants at the coalface. Second, to prepare foreigners who were ignorant of the miners' trade, companies developed training practices by which inexperienced immigrants, under the tutelage of experienced French miners, learned mining skills while on the job. ${ }^{27}$ Third, managers had to ensure that newly trained foreigners maintained high productivity. In response, a policy of encadrement was developed,

23. Ibid., p. 190.

24. ANMT, I 994 048/0004, Procès-Verbaux de la Réunion du Conseil d'Administration de Mines de Marles, 29 Juillet I920: Situation générale; ANMT, I994 048/0003, Notes pour le Rapport à l'Assemblée Générale: Exercice 1920-192 I.

25. Pawlowski, "Un gros problème pour l'industrie du Nord", p. 919.

26. ANMT, I 994 048/0030, Directions des Services techniques, Procès-Verbal de la Conférence I July 1920: Ouvriers polonais. All translations from French are mine.

27. ANMT, I 994 048/0030, Directions des Services techniques, Procès-Verbal de la Conférence I I December I919 zème partie: Ouvriers polonaise; Georges, "Rapport de M. L'Ingénieur en Chef des Mines [...] 1922", p. 319. 
procedures by which French supervisory staff monitored intensely the work of all non-native miners. ${ }^{28}$

These placement, training, and supervisory policies proved successful for Pas-de-Calais mines. Firms effectively funneled immigrants to vacancies underground and away from support positions on the surface. Indeed, by I 924, in Pas-de-Calais mines the ratio of French to foreign workers in surface positions was 8 to I. Yet, at the coalface, the proportion differed considerably with a ratio of I to $\mathrm{I} .{ }^{29}$ Similarly, on-the-job training permitted inexperienced foreigners to achieve output similar to that of experienced French staff within six months of their arrival..$^{3 \circ}$ Lastly, close supervision by French managers through encadrement maintained non-native efficiency. At the Mines de Marles, for example, the percentage of French workers and managers to Polish miners became a standard variable in productivity. Indeed, to preserve production, the company often temporarily suspended assigning Poles to pits with elevated immigrant staff levels. ${ }^{3 \mathrm{I}}$

While they focused on procedures in the workplace to tackle immigrant placement and productivity, mining companies developed policies outside the mines to recruit and retain Poles and to reinforce Polish customs presumed advantageous to employers. Two notions shaped management's approach to the tasks of attracting and keeping Polish workers. First, executives recognized the Poles' appreciation of comfortable company housing and their desire to maintain their cultural and religious customs while in France. Second, executives assumed that foreigners' rootlessness in France greatly contributed to their unsteadiness at work. They surmised that the immigrants' unfamiliarity with the French language, customs, and work habits often deeply frustrated them. Non-native dissatisfaction, in turn, expressed itself in the desire to seek other employment. ${ }^{32}$ In this way, firms concluded that attention to immigrant lodgings and ethnic communities could boost the hiring and maintaining of Polish staff. Companies thus committed themselves to creating a Polish milien national in the coalfields, a culturally familiar atmosphere that would, as one industry authority stated, "keep workers in contact with their former national moral and intellectual life". ${ }^{33}$

To construct it, mines refocused longstanding elements of employer paternalism - company housing, the funding of voluntary associations for

28. ANMT, I 994 048/0033, Directions des Services techniques, Procès-Verbal de la Conférence 4 January 1923: Production; ibid., 25 January 1923: Production; ibid., I 2 July 1923: Production. 29. Georges, "Rapport de M. L’Ingénieur en Chef des Mines [...] 1924", p. I I8.

30. Idem, "Rapport de M. L'Ingénieur en Chef des Mines [...] I922", p. 319.

3I. ANMT, I 994 048/003 I, Directions des Services techniques, Procès-Verbal de la Conférence is September I92 I: Ouvriers polonais; ANMT, I994 048/0032, Directions des Services techniques, Procès-Verbal de la Conference is December 1922: Ouvriers polonais.

32. Pairault, L'Immigration organisée, p. 193.

33. ANMT, $4 \circ \mathrm{AS}_{7}, 26$ November 1920, Secretary of CCHF Circular 608. 
staff, and support for religious institutions for workers - to cater to and profit from the Poles' ethnic preferences and character. This ethnic paternalism guided executives as they allocated the choicest housing to Poles, fearing that poor accommodation would discourage further migration. ${ }^{34}$ In assigning lodging, managers also frequently concentrated Poles into particular tracts of company housing, hoping such moves would boost the immigrants' contentment. Beyond this, companies often constructed entire cités polonaises, or communities devoted exclusively to Polish workers and their families. ${ }^{35}$

Ethnic paternalism also shaped managerial approaches to backing voluntary associations to stabilize immigrant personnel. For example, the companies helped to bankroll athletic, musical, and artistic clubs for their Polish staff, expecting that this would acclimatize them to local living conditions. Support for Polish associations mirrored those available to the larger mining workforce but with one important difference. For French staff, executives favored inclusive organizations with membership open to workers and supervisors alike. Such clubs would, they surmised, build understanding between groups as supervisors and laborers met in common cause and amusement. ${ }^{36}$ Also, these clubs, at least in principle, did not ban non-French members. In the case of Polish associations, however, companies subsidized organizations open exclusively to Poles. ${ }^{37}$ Lastly, ethnic paternalism influenced company support for Polish religious particularism. Indeed, coal firms contributed financially to Polish religious and prayer groups, paid Polish priests to minister in the coal basin, and constructed chapels specifically for Polish worshippers. ${ }^{38}$

Pas-de-Calais mines also maintained a cooperative attitude toward Polish consular and other officials active in the region. This approach served company efforts to ensure access to Polish manpower, as the Polish authorities could influence the flow of emigrants to the mines. Therefore, companies permitted consular staff to tour facilities, to interview Polish employees, and to monitor the immigrants' treatment in the mines. ${ }^{39}$

34. Ibid.

35. "Aux Mines d'Ostricourt: Inauguration de la cité polonaise", Nord Industriel, (1922), p. 2043. 36. "Les CEuvres Sociales dans les Houillères du Nord et du Pas-de-Calais: III", Nord Industriel, (1923), pp. 2288-2289.

37. Ibid., "II", pp. 2244-2245; ibid., "I", pp. 21 52-21 I3; Pairault, L'Immigration organisée, p. 193 .

38. For examples of this support see “Aux Mines d'Ostricourt”, Nord Industriel, (1922), p. 75 I; ANMT, 40AS7, 26 November 1920, Secretary CCHF Circular 608; Pairault, L'Immigration organisée, pp. $252-263$.

39. This cooperation is evidenced in, for instance, Archiwum Akt Nowych [Archive of New Records], Warsaw, Ministerstwo Spraw Zagranicznych [Ministry of Foreign Affairs], Series MSZ, MSZ i I 139, 27 March 1929, Letter from Consul of Poland, Lille, to Director General of Mines de Marles. 
Moreover, they allowed Polish parliamentarians to visit and address Poles residing in company-owned facilities. ${ }^{\circ}$

Coal executives doubtless approved of the apparent influence that ethnic paternalism and cordial relations with the Polish officials had on the Polish workforce. The policies enhanced the recruitment of Polish staff. Indeed, Poles swiftly filled Pas-de-Calais miners' ranks. Companies in the western portion of the coal basin, for instance, employed just 2 Poles in January I919; this number grew to 6,000 by the end of I92 I, more than Io per cent of the labor force there ${ }^{4 \mathrm{I}}$ As the hiring of Poles spread across the coal basin, Polish personnel increased still further, from 16,000 in 1922 to 32,500 in I923, and 38,528 in I924. Thus, Poles represented nearly one-third of the total mining labor force. ${ }^{42}$

From 1925 onward, as coal companies had amassed an adequate workforce, extensive contracting of foreign labor gave way to recruitment to suit market conditions. In periods of slack coal demand, firms neither recruited Polish workers nor sought to retain those whose contracts had expired. In the recessionary year of 1925 , for example, total Polish staff fell by 1,900 , about 5 per cent. Economically promising periods reversed the situation, and companies hired immigrants. For instance, in the boom year of 1929 firms added nearly 6,400 Polish workers. ${ }^{43}$ Further, Pas-de-Calais mines successfully enticed married Poles with families to their employment. Of Polish males entering the French coal industry in 1922 and I923, over one-third arrived with their wives and children. ${ }^{44}$ Among the remainder, many subsequently sent for their spouses and progeny. Pas-de-Calais mines such as Bruay could, therefore, boast that married workers with children constituted 6I per cent of their immigrant staff. ${ }^{45}$

Ethnic paternalism also yielded dividends in enhancing managerial control over non-natives, in reducing turnover among Polish staff, and in ensuring that immigrant children grew up in surroundings which made

40. ADPdC, IZ501, 29 June 1924, Rapport No. 528: Union des Travailleurs Polonais en France, Special Commissar Lens; and ADPdC, IZ50I, 26 February 1924, Commissariat of Police, Bruayen-Artois to Subprefect Béthune re Réunion en Bruay. Special commissars were officials who monitored groups and individuals whose actions were considered potentially subversive and threatening to the French political order and national security. The organizations and actions of foreigners attracted much of the attention of the special commissars. The special commissars reported both to departmental prefects and to security officials of the central government.

4I. Paul Georges, "Rapport de M. l'Ingénieur en chef des Mines sur la Situation de l'Industrie minérale dans l'Arrondissement minéralogique d'Arras pendant l'année 1921", in Département du Pas-de-Calais Conseil Général deuxième Session ordinaire de I92I: Rapports des Chefs de service et Renseignements divers, troisième partie (Arras, 1922), pp. 333-349, 345.

42. Idem, "Rapport de M. L'Ingénieur en Chef des Mines [...] I922", pp. 3 I 8-319, and "Rapport de M. L'Ingénieur en Chef des Mines [...] 1924", pp. I I7-I I 8.

43. Galand, Les Mines $d u$ Nord, p. I35.

44. ANMT, $4 \circ \mathrm{AS}$ I, CCHF Assemblée Générale 1924, p. I4.

45. Pairault, L'Immigration organisée, p. I92. 
them likely future miners. Company housing strategies helped to create a patchwork of Polish communities within Pas-de-Calais. By I924, in twelve of the twenty-three mining-district communes Poles constituted one-half or more of the French population. Further, in six of these communes Poles outnumbered French residents. ${ }^{46}$ Concentrating immigrants into specific communities permitted greater levels of surveillance. Companies, in fact, posted special guards and inspectors in foreign-worker areas, where they served as the employers' eyes and ears. ${ }^{47}$ Management's policies also successfully promoted worker stability. The proportion of Poles leaving the coal industry within a year of their arrival shrank from 35 per cent in I92 I to 16 per cent in 1922, and then to just 2 per cent in $1923 .{ }^{48}$ Further, firms benefitted from family immigration as Polish youths increasingly took up work in the mines. ${ }^{49}$

Ethnic paternalism and other strategies, however, did more than simply advance managerial agendas; they also significantly helped to shape the Polish community that emerged in postwar Pas-de-Calais. At the same time, coal firms did not create it alone. Like French executives, the Polish state, the Polish church, and immigrant Poles also pursued a Polish milieu national in the coalfields. The Polish government, through consular officials, defended the emigrants and advised many ethnic organizations. Polish priests and nuns attended to Polish believers, upholding the Poles' Catholic faith and religious traditions. Moreover, the ambitions and preferences of the immigrants themselves molded the Polish community. Employer efforts thus combined with those of Polish authorities, clergy, and immigrants to create a community enjoying a wealth of social, cultural, religious, and economic institutions. Indeed, no other immigrant group in interwar France possessed an ethnic support network comparable to that of Pas-de-Calais Poles. ${ }^{50}$

The Poles operated, often with financial assistance from employers, a dizzying variety of voluntary associations. A religious orientation underpinned many groups, such as rosary associations, the Society of Saint Vincent-de-Paul, and the Association of Saint Barbara. Other organizations focused on art and culture, staging theatrical and musical performances. Poles also pursued sport, gymnastic training, and outdoor activities in Polish soccer leagues, in athletic clubs, and in Polish boy scout troops. ${ }^{\mathrm{I}}$

46. ADPdC, M323 I, 19 December 1924, Prefect to Direction de la Sureté Générale, Paris.

47. ADPdC, IZ 501 , 25 March I925, Report of Special Commissar Lens to Subprefect Béthune.

48. ANMT, ${ }_{4} \circ \mathrm{AS}$ I, CCHF Assemblée Générale i 924 , p. I4.

49. Georges, "Rapport de M. L'Ingénieur en Chef des Mines [...] I 923 ”, pp. I 28 -I 29.

50. Mauco, Les Étrangers en France, pp. 313-349.

5 I. Ibid., p. 330. For a discussion of this array of associations see, for instance, ADPdC, IZ 501,25 March I 925 , Special Commissar Lens to Subprefect Béthune; and ADPdC, M68 57, 23 September 1929, Subprefect Béthune to Prefect Pas-de-Calais. On Polish sports associations, particularly soccer clubs, in both the Nord-Pas-de-Calais region and the Ruhr, see also the contributions by Marion Fontaine and Diethelm Blecking to this Special Issue. 
Individual communities of Polish miners were awash with ethnic clubs. For example, the Poles in the commune of Bruay alone maintained forty-two separate groups. ${ }^{52}$

Poles also established businesses. In the coalfields a Polish merchant class arose, serving an immigrant clientele. The city of Lens, for instance, became an important site of Polish commerce. The smaller town of Sallaumines also boasted many Polish businesses. In 1924, just five years after the entry of the first contingent of Polish immigrants, Sallaumines counted nineteen different Polish-owned small businesses and Lens hosted forty. ${ }^{53}$ These enterprises met various immigrant needs and wants. Polish-operated banks stored the immigrants' savings and money-transfer services transmitted their funds to Poland. Stores carrying Polish newspapers, magazines, and books catered to the Polish reading public. Additionally, Polish cafés and restaurants flourished, providing immigrant workers and their families with familiar foods and venues for socializing. Most numerous among Polish businesses were small groceries, butcher shops, and bakeries. Their proprietors' understanding of Polish culinary preferences permitted them to serve a market of which French establishments remained largely unaware. ${ }^{54}$

\section{COMPANY POLICIES, NATIVE ANXIETIES, AND IMMIGRANT SOCIAL ISOLATION}

Company efforts to attract, to retain, and to manage immigrants also profoundly shaped Polish-French relations within the multi-ethnic workforce and society emerging in postwar Pas-de-Calais. Overall, the newcomers remained isolated from the wider coalfield society in the I920s. Scholars generally trace the social distance separating the immigrants from natives to the Poles' strong ethnic institutions. These built support among the migrants but left them without meaningful connections to their working-class French neighbors. Further, researchers point out that companies, the Polish state, the Polish church, and the immigrants together constructed the ethnic institutions that cultivated both the Poles' ethnic solidarity and also their social segregation. ${ }^{55}$ Such views, however, overlook

52. Mauco, Les Étrangers en France, pp. 330-331; ADPdC 1Z209, s November 1924, Special Commissar Lens to Subprefect Béthune.

53. ADPdC, IZ501, 4 November 1924, Special Commissar Lens to Subprefect Béthune; and ADPdC, IZ501, 4 January 1925, Special Commissar Lens to Subprefect Béthune.

54. Mauco, Les Étrangers en France, pp. 339-340. For descriptions of the Polish businesses see, for instance, ADPdC, IZ 50 I, 4 November 1924, Special Commissar Lens to Subprefect Béthune; ADPdC, IZ50I, 4 January I925, Special Commissar Lens to Subprefect Béthune; ADPdC, M3229, 22 September 1925, Special Commissar Béthune to Subprefect Béthune.

55. Such interpretations can be found, for instance, in Janine Ponty, Polonais Méconnus: Histoire des Travailleurs immigrés en France dans l'Entre-deux-guerres (Paris, I990), pp. I I 3-I 42 and I47-I72; Gary S. Cross, Immigrant Workers in Industrial France (Philadelphia, PA, 1983), pp. 7 I-98. 
another group that powerfully shaped the immigrants' social position: Pas-de-Calais natives. Further, they fail to appreciate the complex influence that managerial policies toward Poles exerted over ethnic relations.

Ultimately, cool social interactions between non-natives and natives owed much to the cultural and socio-economic anxieties that colored local perceptions of Poles. Coal company policies, for their part, magnified the natives' misgivings and fostered their contempt for foreigners. Inside the mines, managerial procedures toward immigrants led French miners to view their Polish co-workers as occupational inferiors and to eschew workplace friendships with them. In this way, ethnic differences blunted the force of shared work experience to foster the foreigners' integration. Outside the mines, company housing for immigrants, support for Polish ethnic and religious institutions, and employer cordiality with the Polish state limited venues for Polish-French interaction, and it amplified the natives' myriad suspicions of Poles. This distance and distrust hampered the operation of working-class institutions to incorporate immigrants, as Pas-de-Calais trade unionists regarded Polish members with lack of interest or even animus.

Among coal basin natives, the immigrants' arrival sparked alarm over how it would affect the locals' economic and social position. Pas-de-Calais miners feared that foreigners would accept substandard pay and working conditions, permitting management to use them to undermine French wages and job security. ${ }^{56}$ Further, natives worried that immigrants might rob them of opportunities for social and occupational advancement. As more and more miners aspired to abandon arduous and dangerous work underground, they coveted less demanding and high-paying service and maintenance jobs available in rebuilding postwar mines. In pursuit of these, Pas-de-Calais miners did not welcome the prospect of competition from immigrants.

The tactics that coal firms developed to assign, to train, and to supervise Polish labor in the mines helped to transform French economic and social anxieties into a sense of superiority, a sentiment that distanced natives from newcomers in the workplace. Placement procedures funneling immigrants into the most taxing and least valued jobs at the coalface and denying them access to prized surface and maintenance positions powerfully influenced Pas-de-Calais workers' views of foreigners. French miners soon perceived non-natives as their subordinates at work, as a group lacking the ability and even the intelligence to ascend from lowly occupations. On-the-job-training routines for Poles reinforced this assessment. Indeed, foreigners took up their positions only after French miners had instructed them and declared them fit for work. The system of encadrement similarly bolstered native

56. Ralph Schor, L'Opinion Française et les Étrangers en France 1919-1939 (Paris, 1985), pp. $260-263$. 
miners' sense of superiority as it barred Poles from mining without French supervisors. Beyond shaping perception, these training and supervisory policies elevated the actual status of many French miners who took up positions of authority as the trainers and supervisors of Poles.

Native workers relished their elevated position and loathed challenges to it. As one contemporary observer reported, French miners chafed when non-natives received pay and job assignments similar to their own. ${ }^{57}$ Further, they resented Poles who left lowly mining positions to open shops, cafés, and bars. ${ }^{8}$ In their view, the Poles' place was underground, subordinated to the will of French managers, and not clawing their way into the petty bourgeoisie. Thus, managerial policies widened the gap between natives and foreigners in the mines. Indeed, as the Pas-de-Calais prefect related, in the workplace Frenchmen and Poles remained separated by an "invisible wall" across which members of one group offered the other "a brief hello" at best. 99

Mass Polish immigration to the coalfields also proved disconcerting to the cultural sensibilities and outlook of Pas-de-Calais miners. Many coal-basin natives shared a regional identity in which they took great pride and comfort. Most traced their ancestry back to migrants from the countryside of the Pas-de-Calais and neighboring department of the Nord. ${ }^{60}$ And they continued to speak local patois and to delight in regional folklore and customs. In fact, postwar observers remarked that Pas-de-Calais miners felt completely at ease only with other coalfield natives. ${ }^{6 r}$ Such insularity even affected the local workers' movement. Despite strong trade unionism among Pas-de-Calais miners, they seldom focused on concerns beyond those of local interest. Thus, appeals to worker internationalism motivated only a minority. ${ }^{62}$

Beyond regional loyalties, secularism and anti-clericalism united coal basin locals. Indeed, Pas-de-Calais mining communities represented the least religious and most anti-clerical region in all of France. ${ }^{63}$ Wartime invasion, dislocation, and destruction created still other common sentiments among Pas-de-Calais miners. They emerged from World War I deeply suspicious of foreigners, of Germans in particular, and assured in their patriotism. ${ }^{64}$ Polish immigration troubled all these aspects of local

57. Condeveaux, Le Mineur du Nord, p. is.

58. See ADPdC, IZ50I, 4 January I925, Special Commissar Lens to Subprefect of Béthune.

59. ADPdC, M6857, i I October 1929, Prefect Pas-de-Calais report to Interior Ministry.

60. Philippe Ariès, Histoire des Populations françaises et de leurs Attitudes devant la Vie depuis le XVIIe siècle (Paris, 1948), pp. 226-254.

6r. On postwar local culture in general see Condeveaux, Le Mineur $d u$ Nord, pp. 5-ı6.

62. Ponty, Polonais Méconnus, p. I 80.

63. Ibid., pp. I53-1 54. See also Serge Laury, "Aspects de la pratique religieuse dans le diocèse d'Arras (1919-I 945)", Revue du Nord, (197I), pp. I23-I 34, I23-I 24.

64. Ponty, Polonais Méconnus, p. I80. 
culture and mindset as it placed a very alien group in their midst. The Poles' language, customs, and origin differed greatly from those uniting the natives. Their religiosity and reverence for the Catholic Church clashed with local attitudes. Further, the immigrants' allegiance to a nation other than France offended the miners' nationalism. Pas-de-Calais natives thus confronted a group very dissimilar to them.

Company efforts to attract and to root Poles in the coal basin through a Polish milieu national outside the workplace intensified the natives' cultural misgivings toward Poles. These policies thus furthered ethnic separation between the French and Poles in the Pas-de-Calais coalfields. In addition, certain managerial tactics - such as company housing practices concentrating Poles in particular neighborhoods or constructing completely Polish worker cités - much reinforced ethnic divisions. As Leen Beyers has revealed in analyzing immigrant-Belgian interaction in the Belgian mines, segregated housing not only inhibited positive interactions between natives and newcomers, it also fostered indigenous prejudice. By the presence of their surrounding countrymen in Belgian neighborhoods, Belgians felt reassured of the importance of their own ethnic identity, leading them to avoid and disdain immigrants, whom they deemed inferior. ${ }^{65}$

Company accommodations operated similarly in the Pas-de-Calais. Housing assignment based on ethnicity meant that neighborly bonds nurtured by contact, communication, and reciprocity were not likely to develop between the Poles and the French. While companies calculated that residential segregation would strengthen ethnic ties among Polish employees and their families, it worked likewise for Pas-de-Calais natives. The presence of Polish neighborhoods allowed local miners to appreciate all the more clearly the regional culture, the secularism and anti-clericalism, the patriotism, and the suspicion of foreigners that bound them together. Additionally, by backing numerous Polish-only clubs and groups, executives actually left closed avenues for Polish-French interaction and understanding that company-supported inter-ethnic organizations might have opened.

Management's support for Polish religious institutions and courtesy to Polish officials also worked to sharpen native suspicions born of anticlericalism and nationalism. Company funds helped to cultivate a set of cultural practices doubly foreign to Pas-de-Calais miners. Not only was the immigrants' devotion to Catholicism out of place in the profoundly secular coalfields, Polish religious customs, favoring outward and communal expressions of devotion, contrasted with the often more somber and internal forms of French reverence. ${ }^{66}$ As French miners puzzled over Polish

65. Leen Beyers, "Everyone Black? Ethnic, Class and Gender Identities at Street Level in a Belgian Mining Town, 1930-50", in Berger et al. (eds), Towards a Comparative History of Coalfield Societies, pp. I46-163, I 5 I-1 56.

66. Ponty, Polonais Méconnus, p. I48. 
religious life, two questions were in the forefront in their minds. How strong was the influence of Polish priests over the immigrants? And how would Polish clergy intervene in local economic and social matters? Similar questions arose as miners watched Polish officials circulate in mines and mining communities. How much power did these foreign authorities wield over their citizens and to what end might they use it?

At times, Pas-de-Calais natives gleaned troubling answers to these questions. For instance, already in the early i 920s, Polish labor leaders sought to create an ethnic-worker organization independent of the major French unions. This project earned the approval of Polish clergy and consular staff. It also electrified French miners and their unions, who rallied to oppose it. Anticlericalism and patriotism charged their arguments against the Polish group. Union officials questioned the ability of Poles to overcome the influence of Polish priests and to see their own occupational and class interests. ${ }^{67}$ Further, pointing to Polish church and state support for the project, Pas-de-Calais laborites decried such efforts as reactionary and dangerously nationalistic. ${ }^{68}$

By exacerbating cultural differences between Poles and natives, coal company policies outside the workplace contributed to a social climate of indifference and even discrimination toward foreigners. This was manifest in local working-class institutions such as trade unions. Admittedly, at the heights of union leadership, both the reformist union of the Confédération générale de travail (CGT) and the revolutionary/communist union of the Confédération générale de travail unitaire (CGTU) proclaimed common cause with foreign miners. In the fight against capital, both groups vowed to defend the interests of immigrants just as they did French workers. Union leaders, in fact, dedicated some resources to recruiting Poles. They established special sections to address Poles and founded Polish-language publications to communicate with the immigrants. ${ }^{69}$ Yet, their efforts enjoyed limited success. In I929, for example, the CGT had enrolled only 7,500 of some 90,000 Polish immigrant miners in France. ${ }^{70}$

It is clear that these official efforts did not concern, let alone mobilize, the unions' rank-and-file members, who showed scant enthusiasm for recruiting Poles. Some Pas-de-Calais trade unionists, in fact, called for discrimination against immigrants, as they argued against granting Polish miners the right to vote for mineworker delegates. They maintained that Poles would use the ballots not to serve labor interests but to please Polish priests. $^{7 \mathrm{I}}$ Certain communists even advocated violently disturbing public

67. Schor, L'Opinion Française, pp. 262 and 264.

68. ADPdC, IZ501, 29 June 1924, Special Commissar Lens, Report on Union des Travailleurs Polonais meeting.

69. Schor, L'Opinion Française, pp. 239-252.

70. Cross, Immigrant Workers, p. I44.

71. Schor, L'Opinion Française, p. 26r. 
activities such as Polish celebrations and processions, ostensibly to counter the influence of clericalism..$^{72}$ The bulk of Pas-de-Calais laborites, however, remained indifferent to Polish miners. They tolerated immigrant members, but did not push local or national unions to address immigrant concerns meaningfully. This apathy reflected local attitudes toward immigrants; it also undermined the Poles' enthusiasm for French unions. ${ }^{73}$

Social discrimination against Poles in the Pas-de-Calais, however, ultimately remained limited in the I920s. Miners' unions, despite their initial unease with Polish labor organizing, rejected xenophobic policies and continued to seek, though often half-heartedly, immigrant membership. $^{74}$ This stance dampened anti-immigrant sentiment among local unionists in the long run. The immigrants' circumscribed socio-economic status also defused tension. As immigrants generally remained barred from the most lucrative and least taxing positions in the mines, French workers faced little competition from foreigners for prized jobs. In fact, the presence of immigrants in the mines often created supervisory positions for natives. ${ }^{75}$ Further, labor scarcity in the coalfields and postwar prosperity enhanced the miners' security, well-being, and forbearance for immigrants.

Yet, tolerance of foreigners was not acceptance. One contemporary observer reported that Pas-de-Calais natives remained "extremely cool and even distrustful" of foreigners. ${ }^{76}$ Another contemporary scholar of mining noted that in the coal basin there existed between the French and Poles "two such complete worlds, [that] interaction is not always affable". ${ }^{77}$ For his part, the Pas-de-Calais prefect surmised that a Frenchman moved through Polish neighborhoods only as a "passer-by", between the native and the Poles arose neither "companionship" nor "friendship". ${ }^{8}$

\section{COMPANY POLICIES, PAS-DE-CALAIS OFFICIALS, AND ANTI-IMMIGRANT DISCRIMINATION}

Coal company policies toward immigrant staff that amplified native prejudices, suspicions, and discriminatory attitudes toward Poles in coalfield society had similar effects on the French state and its relations with non-natives in Pas-de-Calais. Scholars of interwar French immigration have

72. Ibid., p. 265 .

73. Cross, Immigrant Workers, pp. 94 and $\mathrm{I}_{4} \mathrm{I}-\mathrm{I} 65$.

74. See Copy of the Reports of the Annual Congress of the Syndicat des Mineurs du Pas-de-

Calais for 1923-1924, 20 April 1924, and Copy of the Reports of the Annual Congress of the Syndicat des Mineurs du Pas-de-Calais for 1924-1925, I9 April 1925, in ADPdC, IZ277.

75. Mauco, Les Étrangers en France, p. 475 .

76. Condevaux, Le Mineur du Nord, p. 7.

77. Galand, Les Mines $d u$ Nord, p. 46.

78. ADPdC, M6857, i I October 1929, Prefect Pas-de-Calais report to Interior Ministry. 
recently discovered that in the French government's efforts to administer and police its burgeoning immigrant population during the I920s and I930s, local officials possessed considerable autonomy and authority. They reveal that legislators and ministers of the central government crafted immigration regulations and directives according to their own principles and purposes. And these researchers have illuminated the way in which local contexts, conditions, and attitudes affected the implementation of immigration regulations emanating from Paris. ${ }^{79}$ Departmental and municipal officials thus applied and enforced laws in ways shaped to a high degree by their local concerns, sentiments, and fears. Yet, by largely restricting their analytical attention to interactions between the state and immigrants, these studies have inadequately explored the considerable influence that employers exercised over the perceptions and concerns of the local officials who policed foreigners. This influence over state-immigrant interrelations, however, was considerable, even though largely unintended.

In the Pas-de-Calais, the postwar flood of immigrants to the coalfields produced a host of weighty administrative and security concerns for local authorities. Coal firms inadvertently fueled these preoccupations. By supporting Polish clergy, churches, religious associations, and ethnic organizations in the coalfields and by remaining friendly with Polish officials in the region, coal firms hoped to bolster the recruitment, retention, and managerial control of Polish staff. Watchful for any immigrant challenge to national security and the power of the French state, local officials, however, perceived the Polish milieu national differently.

Broadly, French officials regarded the actions and attitudes of Polish immigrants, clergy, and authorities as affronting the republican creed that guided the French Third Republic, the state they served. French republicans championed a set of universal rights, liberties, and responsibilities that would be open to all who wished to take citizenship, regardless of their origin. They expected the beneficiaries of liberty, equality, and fraternity to surrender loyalties to tradition in order to participate fully in the larger French linguistic and cultural community. Republicans thus regarded the use of the French language and secularism in public life as crucial to the unity and strength of the republic. ${ }^{80}$ Though not citizens, immigrants

79. For examples see Paul Lawrence, “'Un flot d'agitateurs politiques, de fauteurs de désordre et de criminels'. Adverse Perceptions of Immigrants in France Between the Wars”, French History, I4 (2000), pp. 201-22 I; Clifford Rosenberg, Policing Paris: The Origins of Modern Immigration Control between the Wars (Ithaca, NY, 2006); and Mary Dewhurst Lewis, The Boundaries of the Republic: Migrant Rights and the Limits of Universalism in France, 1918-1940 (Stanford, CA, 2007).

80. Rogers Brubaker, Citizenship and Nationhood in France and Germany (Cambridge, MA, 1992); Edward Berenson, Vincent Duclert, and Christophe Prochasson (eds), The French Republic: History, Values, Debates (New York, 20I I); also see Marion Fontaine's contribution to this Special Issue. 
nevertheless aroused official consternation and even anxiety when they clung to their native languages and traditions and lived in tight-knit ethnic communities. To republican eyes, such tendencies could appear to threaten national unity and the political order itself.

To Pas-de-Calais officials, then, the Polish worker cités and the networks of ethnic and religious institutions in them did not appear to be sites and implements for employer control. Instead, they saw them as bastions and tools of foreign influence and power, sites where Polish priests and officials mobilized ethnic organizations and immigrants to serve interests separate from or contrary to those of France. Local officialdom, thus, came to view Poles as a suspect group, one warranting enhanced surveillance and harsh treatment.

The rapidly growing immigrant population after World War I created manifold responsibilities for departmental and municipal officials in the Pas-de-Calais. The central government in Paris called on its subalterns across France to administer and police immigrants in the nation's economic, public safety, and security interests. Paris sought to ensure employers' access to needed foreign labor, while protecting the French workforce from unfair competition. Thus, it tasked local administrators with regulating the labor contracts and residency requirements governing the immigrants' occupation in France. Further, the central government worked to shield citizens from any threats to public safety and property that immigrants might pose - a potential that was regarded at the time as real and rather acute. And, it pledged to defend French political institutions, sovereignty, and national unity from what was perceived as the possible machinations of alien political extremists and of governments seeking undue influence over their emigrants in France. To serve public safety and national security, Paris called on local officials to exert particular vigilance in policing the immigrants in their jurisdictions. ${ }^{81}$

To meet the administrative and law enforcement challenges associated with the presence of the foreign population, the central government placed arbitrary powers in the hands of departmental and local officials. For instance, they could put a suspect immigrant on refoulement, an action placing the migrant's right to remain in France on probation. Beyond this, local authorities could recommend that a foreigner be expelled outright. Law enforcement could issue refoulement and expulsion orders largely as it pleased. Transgressions warranting these punishments were not codified, and foreigners lacked the right to appeal such decisions against them in court. ${ }^{82}$

8I. For further details about the security-dominated policies of the French state vis-à-vis immigrants, see Philip H. Slaby, "Industry, the State, and Immigrant Poles in Industrial France, 1919-1939" (Ph.D. dissertation, Brandeis University, 2005), pp. 205-2 I 3.

82. Jean-Charles Bonnet, Les pouvoirs publics français et l'immigration dans l'entre-deux-guerres (Lyon, 1976), pp. 106-107; Schor, L'Opinion Française, p. 281; Cross, Immigrant Workers, pp. I 8 I-I 82 . 
Some of the varied administrative and law enforcement tasks associated with immigration frustrated the Pas-de-Calais authorities. Regulating the immigrants' position in the workforce created considerable administrative burdens for local officials. For instance, enforcing the labor contracts of Poles who broke agreements and drifted from employer to employer proved exasperating. Tracking down job-hoppers alone consumed great effort, as wayward immigrants often simply departed for new prospects without leaving a clue about their destinations. ${ }^{83}$ While regulating the foreigners' place in the workforce represented administrative drudgery, Pas-de-Calais officials eagerly responded to calls to safeguard national political institutions, sovereignty, and unity from any immigrant menace. In fact, Pas-de-Calais officials pursued immigrants they deemed dangerous to the French political order and national security with such ardor that they clashed with their superiors. At times, ministries in Paris reprimanded Pas-de-Calais administrators and police for their high-handedness toward suspect foreigners. For their part, local officials, convinced of the gravity of immigrant threats, often dismissed and defied calls from Paris for restraint and evenhandedness. ${ }^{84}$

For Pas-de-Calais officials, the Polish mining community became a focus for much suspicion. And coal company policies toward Polish staff certainly shaped the features of the community that local authorities found disquieting. As explained above, management residentially segregated Poles, funded organizations to reinforce Polish cultural habits, built Polish churches and salaried Polish clergy, and maintained good relations with figures from the Polish state. Given Pas-de-Calais officialdom's preoccupation with upholding the strength and authority of the French republic, it is no surprise that they had doubts. To what entities and to whom did socially isolated Poles owe loyalty? For what political or other purposes did ethnic institutions operate? What leadership did Polish priests and officials exert, and for what goals?

One of the major issues was that immigrant Poles, in the estimation of local authorities, were politicized and nationalistic. The special commissar of Lens clearly expressed these views. Poles were in his estimation "extremists of the left or of the right", and seven Poles in ten were "thoroughly nationalist", by his reckoning. Further, he had "no illusion regarding Franco-Polish friendship". True, he noted, Poles publicly pronounced "good intentions" toward France, but he judged such declarations "superficial", existing "only in

83. See the lamentations voiced in the following letter: ADPdC, $\mathrm{M}_{32 \mathrm{I}}$, 25 October 1929, Commissar of Police, City of Sallaumines, to Prefect Pas-de-Calais.

84. On tensions between central government officials, local officials, and immigrants, see Philip H. Slaby, "Violating the 'Rules of Hospitality': The Protests of Jobless Immigrants in DepressionEra France", in Matthias Reiss and Matt Perry (eds), Unemployment and Protest: New Perspectives on Two Centuries of Contention (London [etc.], $201 \mathrm{I}$ ), pp. 175-198. 
speeches and writings". Poles, he concluded, cared little for the future of the country. ${ }^{85}$ Further, in Polish ethnic organizations, local officers saw institutions utterly devoted to advancing the interests of Poles. Beyond this, immigrant associations eroded national unity, as Poles flocked to them and not to French associations, where foreigners could grow to understand their French hosts. ${ }^{86}$ Meanwhile, Pas-de-Calais officialdom's greatest misgivings surrounded Polish priests and consular staff active in the coalfields, in whom they saw leaders who exploited Polish national and religious sentiment to organize and direct immigrants. For instance, one official asserted that the Polish state, through consular authorities and priests, "dragooned" immigrants into ethnic institutions where the "love of Poland and religion" was the central tenet. ${ }^{87}$

Charged to protect national security and possessing discretionary powers, local authorities often acted upon the supposed political dangers posed by the Polish mining community. Public meetings of all types organized by Poles attracted police surveillance. Further, any event at which Polish consular staff or visiting Polish officials appeared drew particular police attention. When such Polish notables toured the Pas-de-Calais coal basin, they did so shadowed by French officials. ${ }^{88}$ The police also went beyond surveillance. Local law enforcement regularly expelled foreign communists, and they brandished the threat of removal to force immigrants of all political orientations into compliance. ${ }^{89}$ Thus, the Poles became both a community under suspicion and one facing official discrimination.

Still, a variety of factors checked state discrimination against Pas-de-Calais Poles during the i920s. This became apparent when local administrators relished and hoped to expand their powers to police the Polish community. For instance, the special commissar of Arras lobbied for the creation of "social laws" to thwart "the excessive chauvinism of some Polish leaders". ${ }^{\circ}$ However, two factors hindered such efforts. First, the

85. ADPdC, IZ50I, Io October 1924, Special Commissar Lens to Subprefect Béthune.

86. ADPdC, M6857, I I October 1929, Prefect Pas-de-Calais report to Interior Ministry; ADPdC, M6857, 30 September 1929, Special Commissar Arras to Prefect Pas-de-Calais; ADPdC, IZ50I, 25 March 1925, Special Commissar Lens to Subprefect Béthune; ADPdC, M3229, 22 September 1925, Special Commissar Béthune to Subprefect Béthune.

87. ADPdC, IZ 50 I, Io October 1924, Special Commissar Lens to Subprefect Béthune. See also ADPdC, IZ501, 25 March 1925, Special Commissar Lens to Subprefect Béthune; and ADPdC, M3229, 22 September 1925, Special Commissar Béthune to Subprefect Béthune.

88. ADPdC, IZ501, 29 June 1924, Rapport: Union des Travailleurs polonais meeting, Special Commissar Lens; and ADPdC, IZ50I, 26 February 1924, Commissariat of Police, Bruay-enArtois, to Subprefect Béthune re: Réunion en Bruay.

89. ADPdC, IZ5OI, I4 October 1924, Subprefect report on immigrant workers to cabinet official. See also ADPdC, IZ 50 I, 20 December 1924, Special Commissar Lens to Subprefect Béthune; and ADPdC, IZ 501 , 4 January 1925, Special Commissar Lens to Subprefect of Béthune. 90. ADPdC, M6857, 30 September 1929, Special Commissar Arras to Prefect Pas-de-Calais. 
central government gave them no real credence. Though many lawmakers denounced isolated immigrant communities and resented foreign diplomats exercising authority over their nationals in France, they offered nothing to combat these. Ultimately, the French government could establish no practical procedures to force open ethnic communities and to halt foreign consulates. The Polish state stood as both a friend of France and as an ally against Germany. To bar contact between the Polish government and its citizens abroad would have sparked unwanted antagonism between the two states. Further, the Polish government could respond to such a move by restricting immigration to France, thereby cutting France off from an important source of necessary labor. For similar reasons, the government could not outlaw the immigrants' freedom to assemble in ethnic organizations or in religious congregations.

A second factor limiting efforts to break the apparent influence of Polish officials and clergy and thus diminish the social isolation of Poles were local attitudes toward coal company policies. Local officials never took aim at the pivotal role that coal companies' efforts played in segregating Poles. While company housing policies actually produced a Polish majority population in certain tracts of housing, managerial responsibility in encouraging ethnic segregation received no official condemnation. Likewise, company support for Polish cultural and religious particularism earned little mention in official exchanges. The Pas-de-Calais authorities seldom pointed out that mining companies had joined the Polish state and clergy in efforts to hinder the Poles' incorporation into the broader society. ${ }^{9 \mathrm{I}}$ Implicating powerful and prominent coal executives in creating foreign enclaves and thereby allegedly threatening national unity and the republican order appears to have been an unattractive prospect to local authorities. Holding a foreign state and church principally responsible for obstructing Polish assimilation proved a more comfortable case to make.

\section{CONCLUSION}

In the decade after World War I, Pas-de-Calais coal firms faced the challenges and opportunities of establishing and managing a multi-ethnic workforce. Polish workers offered them the chance to remedy labor shortages and to re-establish a productive and reliable labor force in the war-torn mines. Yet, to realize the potential that immigrants offered, companies had to grapple with thorny questions of how to attract, how to maintain, and how to manage newcomers. Notions of ethnic and national identity powerfully shaped coal company responses to these issues. Indeed, 
a strategy of ethnic paternalism guided much of management's approach toward Polish staff. To entice Poles to the mine, to reduce turnover among them, and to enhance managerial influence over them, companies endeavored to create a Polish milieu national in the coalfields. They offered Poles housing in ethnic neighborhoods; they helped fund ethnic associations for Poles; and they actively and substantively supported Polish religious life. Beyond these efforts, executives remained friendly toward Polish consular officials.

Not only did aspects of ethnicity shape coal firm policies; managerial tactics also influenced perceptions of ethnic and national difference in the region. Workplace practices that relegated Poles into low-status, demanding underground tasks and that placed them under the authority of French trainers and managers encouraged native miners to perceive themselves as dissimilar from and even superior to foreigners. Further, policies that encouraged Polish residential segregation, a separate Polish associational life, Polish Catholic practice, and the presence of Polish clergy and officials in mining towns helped to underscore ethnic and national dissimilarities between natives and newcomers. Taking pride in their regional and French identity and in secularism and anti-clericalism, Pas-de-Calais miners saw the Poles as different or even menacing. Local miners thus greeted Poles with indifference or contempt.

Management activity sustaining Polish ethnic and religious life and relations between the immigrants and their home government also fueled suspicions vis-à-vis Poles among French officials in the Pas-de-Calais. Local authorities were dedicated to maintaining French strength and to a brand of republicanism that regarded the use of the French language and assimilation into the secular French culture as fundamental to the health of the French republic. To French officials a vibrant Polish mining community demanded strict, if not high-handed, policing. To them, Polish neighborhoods and organizations promoted the influence of the Polish church and state in France, while sustaining the immigrants' linguistic, religious, and cultural particularism. The coal firm policies of fostering this particularism thus interfered with the prevalent official ideas of ethnic, regional, and national identity. In this way, employers significantly contributed to the interrelations of mines, society, and state administration in the Pas-deCalais coalfields.

The patterns of immigrant-native interaction that emerged after World War I had legacies for the larger interwar period. For employers, managerial strategies inside the mines and outside the workplace to entice and retain Polish workers and to make them productive succeeded. Yet, as native miners came to associate dangerous and demanding underground work with immigrants, companies became increasingly dependent on Poles to fill these positions. Even during the Great Depression, mines had to maintain and at times expand their Polish workforce. For local society, the perception 
of Poles as separate from the wider working-class community and its institutions persisted in the I930s. Native miners continued to regard Poles largely with indifference. For instance, early in the Depression, native miners and unions did little to protect immigrants from dismissal from the mines and expulsion from France. The worker-friendly years of the Popular Front government, however, witnessed strengthening ties between Polish and French miners, as immigrants participated in mass strikes and flocked to French unions. Yet, such attitudes did not translate into sustained respect for non-natives. Unions diluted immigrant influence within their ranks and devoted scant attention to foreigners' concerns..$^{92}$ By 1938, such deafness to Polish interests caused many immigrants to abandon French unions. ${ }^{93}$

For Pas-de-Calais officials, their disdain for the Polish community intensified in the I930s. In fact, as parts of the French public and the central government called for immigrant repatriation to open jobs for Frenchmen, Pas-de-Calais officials increasingly acted upon their resentments of Poles. Indeed, for much of the Depression era local authorities, seeking the immigrants' expulsion, aggressively policed Polish labor contracts and political activity. In 1934 alone, they assisted in the deportation of some 3,250 Poles. ${ }^{94}$ For the Poles, the postwar patterns of native-immigrant interaction had perhaps the greatest implications. While the milieu national continued to offer them the support of their countrymen and traditions, the ethnic differences, social isolation, and the suspicion that Polish communal life encouraged often left them to experience growing marginalization and discrimination in the 1930 . Poles would have to wait until the post-WorldWar-II era to experience meaningful integration into French society.

92. Cross, Immigrant Workers, pp. 20I-208, and Schor, L'Opinion Française, p. 642.

93. Ibid., pp. $70 \mathrm{I}-704$.

94. Slaby, "Violating the 'Rules of Hospitality”, p. I93. 